$\begin{array}{cc}\begin{array}{c}\text { Yanbu Journal } \\ \text { of } \\ \text { Engineering } \\ \text { and Science }\end{array} & \text { Vol. 7, October } 2013(1434 \mathrm{H}) \\ \text { www.yjes.org.sa }\end{array}$

\title{
VES AND GPR INVESTIGATIONS TO DELINATE BURIED OBJECTS, CAVITIES AND WEAK ZONES INSIDE AN OIL ESTABLISHMENT SOUTHERN IRAQ, WITH THE ASSISTANCE OF HYDROGEOLOGICAL AND GEOTECHNICAL INFORMATION
}

\author{
Emad H. Al-Khersan \\ Basrah University, College of Science, Iraq
}

\begin{abstract}
Seven vertical electrical sounding points (Schlumberger array) and 32 profiles of ground penetration radar were chosen to completely cover the study area in an industrial establishment site located southern of Iraq / Basrah City. Geotechnical and hydrogeological investigations were also carried out as additional tools to enhance the detection of water table, buried bodies, cavities and weak zones as well as the resulting channels underlying the considered site. Several pronounced anomalies noticed in resistivity and radar sections that indicate the existence and extension of the underneath cavities were presented and analyzed.
\end{abstract}

Keywords: VES, GPR, buried objects and cavities, soil settlement, SPT and bearing capacity.

\section{INTRODUCTION}

The studied area including Site-1 and 2 located southern Iraq / Basrah Governorate and covers about $1.2 \mathrm{Km}^{2}$ for each site has coordinates of $30^{\circ} 26^{\prime} 54.18^{\prime \prime}$ to $30^{\circ} 27^{\prime} 23.39^{\prime \prime} \mathrm{N}$ and $47^{\circ} 39^{\prime} 31.36^{\prime \prime}$ to $47^{\circ} 40^{\prime} 1.59^{\prime \prime E}$ (Fig.1). It represents an industrial establishment that encountered soil settlements problem since 1988. Geologically, the area is mainly composed of alluvial and flood plain deposits which represent Quaternary Dibddiba Formation, Buday [1]. In general, the stratigraphic column for the drilled boreholes inside the investigated area shows that the underlying beds were mainly consist of silty sand in shallow depth and clayey silty sand associated with gypsum layer. The routine work within the area under_study yield sewage of sulfuric water which penetrates through the porous substrate soil, causing the dissolution of gypsiferous cementing materials, hence, subsurface cavities and weak zones (disintegrated zones) develop. This case causes a dangerous problem that may lead to establishment settlement. Subsurface cavities most commonly occur as solution cavities in saline rocks, while, weak zones were hardly presented in the consolidated sand and clay layers.

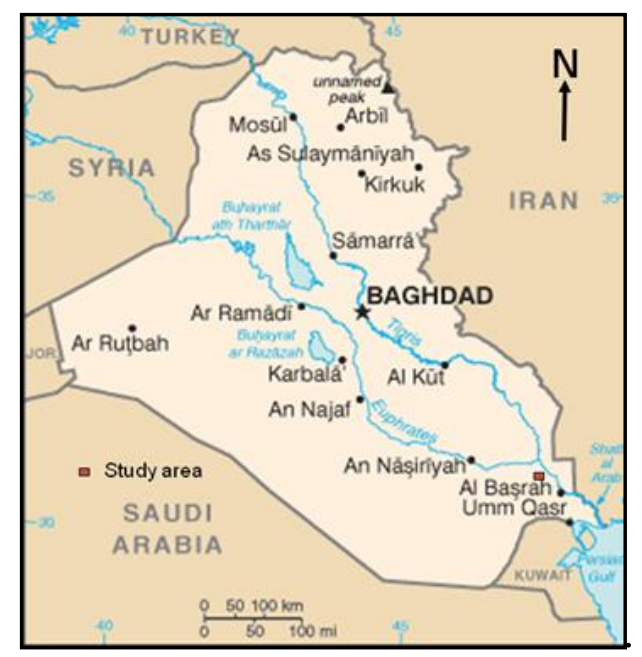

Fig.1. Location of the study area 
These cavities are either empty or filled with collapse soil, water or waste light oil. High resistivity contrast with the surrounding soil may be noticed if the caves are filled by nonconductive hydrocarbon or other fluids, Griffin [2], while the Ground Penetrating Radar (GPR) response is mainly inversely related to the soil conductivity.

Caving problems within industrial sites were studied by many investigators; Al-Ani [3] studied the subsurface cavities in Iraq at Hammam Al-Aleel district / Mosel Governorate, using apparent resistivity method. Al-Jiboury [4] used VES and horizontal profiling to trace the possible locations of weak zones and cavities within an industrial site at Makhul area, northeastern Iraq. Al-Khersan [5] applied Wenner array to detect the same targets in Nassryia Refinery Site. However, Saeed [6] applied GPR and VES site investigations inside Baghdad University to detect the same buried pipes and cables. Moreover, Al-Khafaji [7] also performed his study inside Al-Abbas Holy Shrine site within Karbala governorate, Middle of Iraq, in order to delineate soil foundation of this site. However, Al-Khazali [8] tried to detect the same targets inside Basrah University and Basrah Sport City, Southern Iraq using resistivity and GPR techniques.

The main task of this project is to locate buried objects, cavities and weak zones; and thenafter, to delineate soil settlements that may develop inside the study area and to suggesting appropriate solutions for this problem.

\section{BACKGROUND THEORY}

\subsection{Vertical Electrical SOUNDING-VES}

Resistivity method is one of the simplest geophysical techniques used to measure earth conductivity, but it is still employed extensively because of its easy using and relatively easy interpretation. The grains are considered electrical insulators and the conduction is concentrated to the pore space that is typically filled or partly filled with water. Therefore, resistivity of soils is strongly influenced by the amount of water, which is determined by the porosity and the degree of saturation, Sharma [9].

The Schlumberger array is used in this study. The particular feature of this array is that the potential electrode spacing $(\mathrm{MN})$ is very much smaller (about $1 / 5$ to $1 / 6$ ) than the current electrode spacing. The Schlumberger array uses four electrodes. The current electrodes are represented by $\mathrm{AB}$ and the potential electrodes by MN Al-Menshed [10]. VES is designed to provide vertical profiles of resistivity versus depth. This technique is based on the general observation that current penetrates deeper into the subsurface with increasing separation of electrodes. In an electrical sounding, the electrode array is systematically made larger while the center of the array remains fixed over the area of interest. As the array gets larger, the electric currents flowing deeper and deeper in the earth are sensed, and so the resistivity of deeper and deeper structure is measured, Dobrin and Savit [11].

\subsection{GROUND PENETRATION RADAR-GPR:}

GPR is a near-surface geophysical technique that allows investigators to discover and map (depth and dimensions) buried features by new form of analysis in ways not possible using traditional field methods. It gives the real image of underground objects as radar images in real time during the measurements, Conyers [12].

The generation of electromagnetic waves depends on the relationship between the electric and magnetic fields, a changing magnetic field $(\mathrm{H})$ will induce an electric field 
(E) (Ampere's Law), and a changing electric field will induce a magnetic field (Faraday's Law). The electric and magnetic fields propagate in the same direction but perpendicular, Stolarczyk and Peng [13], (Fig.2). Any dielectric material will dissipate part of the energy from an EM propagating though it. The

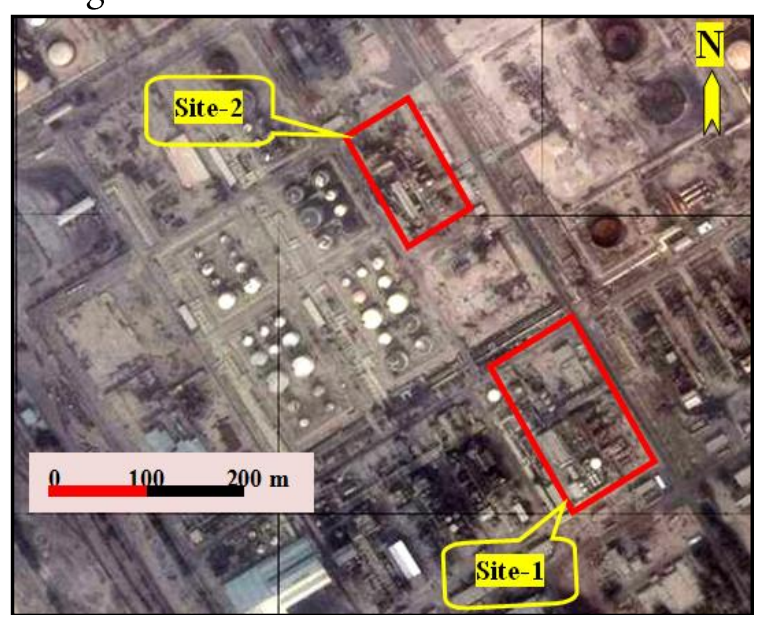

Fig.2. Generation and propagation of EM wave http://micro.magnet.fsu.edu

In regard to media of low conductivity such as soils, rocks, fresh water, and so on, the propagation speed (V) of an electromagnetic wave can be derived as follows Flohrer and Popel [14].

$\mathrm{V}=\frac{\mathrm{C}}{\sqrt{\varepsilon_{\gamma}}}$

$\mathrm{C}$ : propagation speed of electromagnetic wave in air.

$\varepsilon_{\gamma}$ : relative dielectric constant of the material to vacuum.

The amount of reflection depends on the difference of relative dielectric constants of the contrasting two materials. Reflection coefficient $(\mathrm{R})$ can be derived as follows:

$\mathrm{R}=\frac{1-\sqrt{\varepsilon_{2} \sqrt{\varepsilon_{1}}}}{1+\sqrt{\varepsilon_{2} \sqrt{\varepsilon_{1}}}}$

$\varepsilon_{1}$ and $\varepsilon_{2}$ are both relative dielectric constants of the two materials. Relative dielectric constant is an important factor for GPR surveys because it controls propagation velocity of EM waves through material in earth, and it can be a function for mineralogy, porosity, pore fluids, frequency, geometries and electrochemical interactions between rock components, Martinz and Byrnes [15].

\section{METHODS AND DATA USED}

Four soil investigating boreholes (BH.1, BH.2, BH.3 and BH.4) were drilled in two locations (Site-1 and Site-2) inside the area under_study in order to delineate the bearing capacity and other geotechnical properties of the soil, however, groundwater flow direction is also identify. In this study, two geophysical methods were used. These are resistivity and GPR methods which were applied using Both Sweden Terrameter SAS-4000 and Mala Geoscience GPR RAMAC system with shielded monostatic antennas of $250 \mathrm{MHz}$. Each technique has its own modern and advanced instrumentation since they are different in their basic principles. In these surveys, the instruments were borrowed from Geology Dep. / College of Science-Basrah University. However, seven vertical electrical sounding points (red points) using Schlumberger array and 32 GPR profiles (yellow lines) were done in the above two sites using different instrument settings in order to determine the vertical variations within the resistivity values and the corresponding anomalies expected to found in the radargrams (Figs.3, 4 and 5).

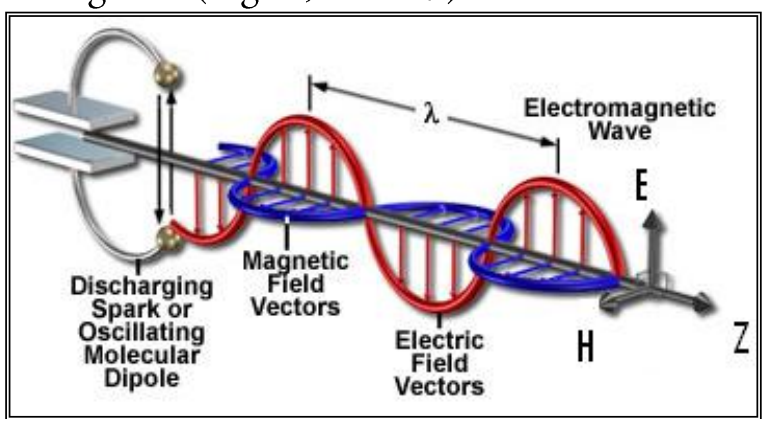

Fig.3. Study area including Site-1 and Site-2 


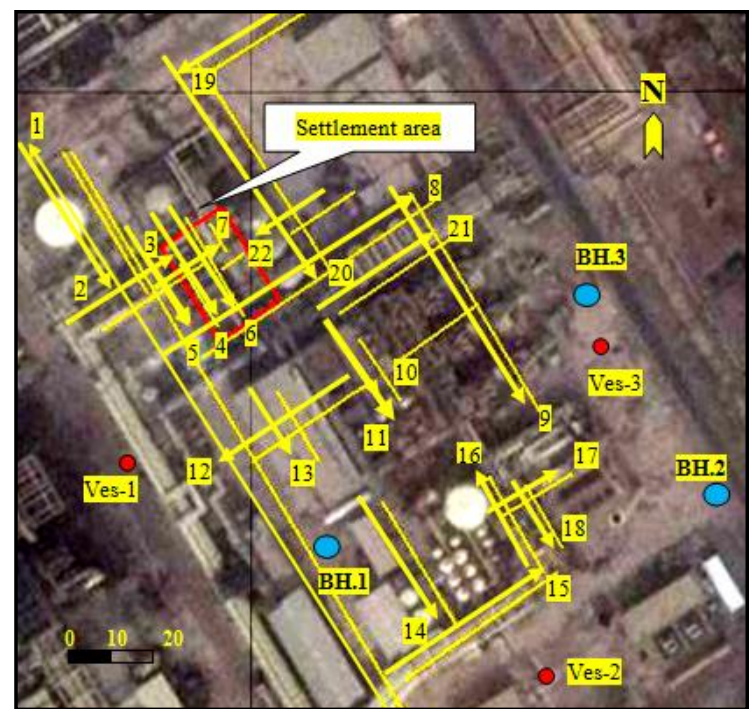

Fig.4. Site-1 illustrating boreholes, VES points and GPR profiles

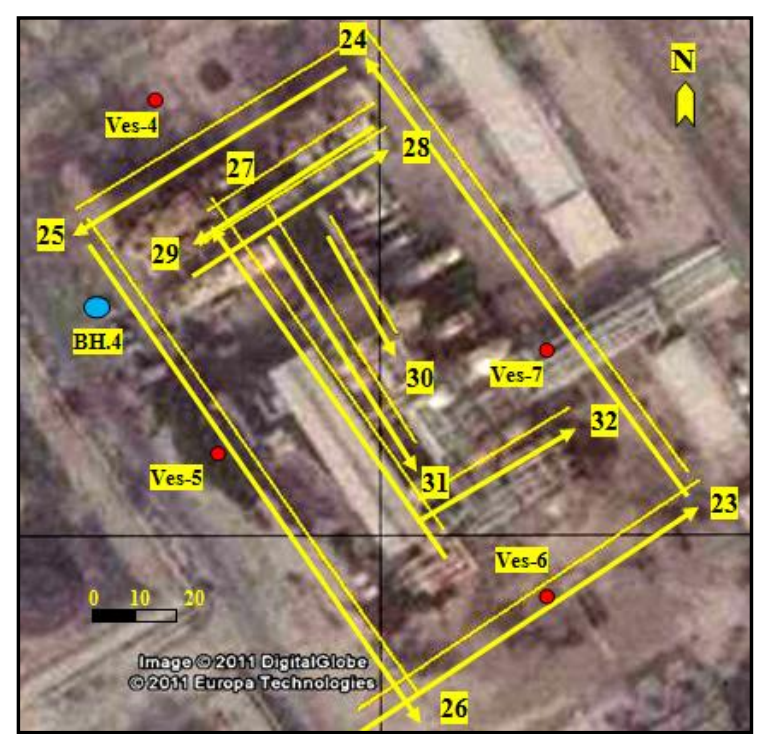

Fig.5. Site-2 illustrating borehole, VES points and GPR profiles

\section{RESULTS AND DISCUSSION}

\subsection{GROUND WATER}

As shown by the groundwater table extracted from the drilling boreholes (Table-1), and the plotted flow map of Site-1 (Fig.6), the groundwater direction is flowing from west and south west to the east and north eastern parts of the study area, in which the above parts including (BH.1) and (BH.2, BH.3) can be regarded as a recharging/ infiltration and discharging zones respectively. Recharging zone represents water leaking area from the wastes of the processing units which finally infiltrates to groundwater. However, it is clear from this table, that the groundwater level in BH.4 locates at Site- 2 is higher than those in BH.2 and BH.3. So, we can conclude that the area including Site- 2 may be regarded as a recharge area too.

TABLE.1: GROUNDWATER LEVELS IN BOREHOLES FOR SITES 1 AND 2

\begin{tabular}{|l|l|l|}
\hline $\begin{array}{l}\text { Site } \\
\text { No. }\end{array}$ & $\begin{array}{l}\text { Borehole } \\
\text { No. }\end{array}$ & $\begin{array}{l}\text { Water Table (m) } \\
\text { above sea level }\end{array}$ \\
\hline \multirow{4}{*}{1} & BH.1 & 4.10 \\
\cline { 2 - 3 } & BH.2 & 3.60 \\
\cline { 2 - 3 } & BH.3 & 3.70 \\
\hline 2 & BH.4 & 4.30 \\
\hline
\end{tabular}

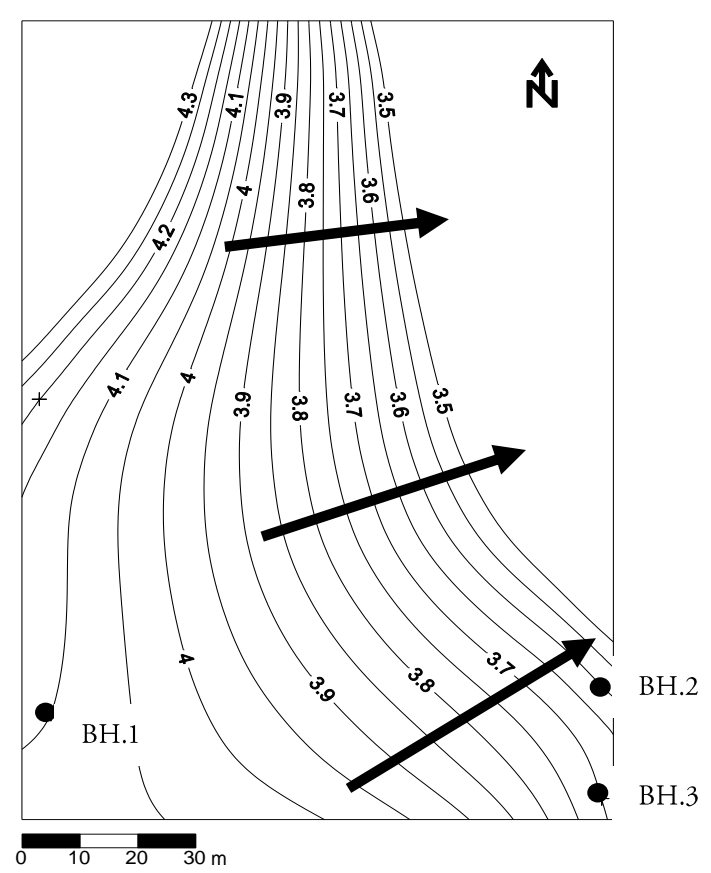

Fig.6. Groundwater flow direction map belong to Site-1

Chemical analysis was also performed for four groundwater samples extracted from each borehole in order to measure several variables, such as acidic degree $(\mathrm{pH})$, conductivity, major cations, anions and hydrocarbons in water, (Table-2). It reveals that light hydrocarbon existed in water exceeds more than $60 \%$ in BH.1 (Site-1). This may lead to promote the settlement problem in this site so many times and in the future. Analysis also 
shows that all groundwater samples are referred to the class $\left(\mathrm{Na}-\mathrm{Cl}\right.$ and $\mathrm{Na}-\mathrm{SO}_{4}$ types) according to their ionic concentrations: $\mathrm{Na}>\mathrm{Ca}>\mathrm{Mg} ; \mathrm{SO}_{4}>\mathrm{Cl}>\mathrm{HCO}_{3}$

TABLE 2: CHEMICAL ANALYSIS OF GROUNDWATER SAMPLES TAKEN FROM DRILLING BOREHOLES

\begin{tabular}{|l|l|l|l|l|}
\hline \multirow{2}{*}{ Chemical analysis } & \multicolumn{4}{|l|}{ Borehole No. } \\
\cline { 2 - 5 } & $\begin{array}{l}\text { BH. } \\
1\end{array}$ & $\begin{array}{l}\text { BH. } \\
2\end{array}$ & $\begin{array}{l}\text { BH. } \\
3\end{array}$ & $\begin{array}{l}\text { BH. } \\
4\end{array}$ \\
\hline $\mathrm{PH}$ & 7.4 & 7.2 & 7.4 & 7.4 \\
\hline $\begin{array}{l}\text { Conductivity } \\
\left(\mathrm{us.cm}^{-1}\right)\end{array}$ & 8930 & 4670 & 4970 & 7720 \\
\hline $\mathrm{Ca}^{+2}$ (ion) (mg/L) & 781 & 761 & 707 & 762 \\
\hline $\mathrm{Mg}^{+2}$ (ion) (mg/L) & 244 & 89 & 162 & 423 \\
\hline $\mathrm{Na}^{+}$(ion) (mg/L) & 979 & 352 & 457 & 1088 \\
\hline $\mathrm{SO}_{4}$ (ion) (mg/L) & 2550 & 1700 & 1800 & - \\
\hline $\mathrm{Cl}^{-}$(ion) (mg/L) & 1530 & 551 & 715 & 1701 \\
\hline $\begin{array}{l}\mathrm{HCO}_{3}(\mathrm{mg} / \mathrm{L}) \\
(\text { ion) }\end{array}$ & 351 & 290 & 137 & - \\
\hline $\begin{array}{l}\text { Light hydrocarbon } \\
\text { in water (\%) }\end{array}$ & - & - & - & $>60$ \\
\hline
\end{tabular}

\subsection{GEOTECHNICAL TESTS}

Distinct variations in the soil composition with depth were recognized (Table-3). As seen by this table, cementing materials carbonate $\left(\mathrm{CaCO}_{3}\right)$ and gypsum are ranged (10-35) \% and (7.31-15.53) \% respectively. These high percent values may cause significant damage in the soil when they dissolve.

Concerning with bearing capacity tests conducted at the drilling boreholes during this study at Site-1; the average bearing capacity value for the three boreholes ranged between (9.5-17) Ton $/ \mathrm{m}^{2}$, and the present value for BH.4 (Site-2) ranged between (8.519.7) Ton $/ \mathrm{m}^{2}$ (Table-4), Table 4 present the values of encountered Standard Penetration Test (SPT) vales. However, the designed bearing capacity for the whole area under_study is about $30 \mathrm{Ton} / \mathrm{m}^{2}$. Therefore, there is a clear deterioration in the soil characteristics occurred owing to the continuous leaking results from available processing units (Fig.7).

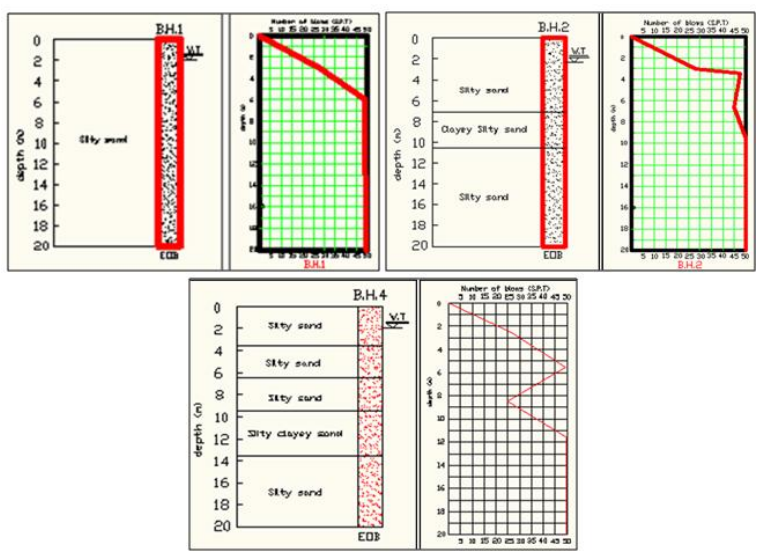

Fig.7. Subsoil lithology and SPT curves for boreholes 1, 2 and 4

\section{GEOPHYSICAL INTERPRETATION}

\section{a. Electrical data interpretations}

Partial curve matching technique Zohdy [16] was used to interpret the electrical data by applying qualitative and quantitative techniques using IPI2Win software. Three vertical electrical sounding points (Ves-1, Ves2 and Ves-3) and four measuring points (Ves4, Ves-5, Ves-6 and Ves-7) were surveyed using schlumberger array inside Site-1 and 2 respectively (Figs.8 and 9). The aim of this survey is to understand the variations occurred in the subsurface resistivity values verses depth and therefore, to determine beds depths, thicknesses, apparent resistivity values and depth to groundwater table. Moreover, it helps in characterizing low resistive underlying layers which can negatively affect the GPR response. According to the obtained results, four layers were observed at both Ves.2 and Ves.3. The first one extends from the surface to average (1.49) $\mathrm{m}$ of depth and a resistivity of (46.85) Ohm.m. Th is is because of the occurrence of unsaturated soft soil; whereas the second layer has depth of (4.15) $\mathrm{m}$ and an average values of resistivity of (73.87) Ohm.m resulting from soil interval saturation. The averages of depth and resistivity values belong to the third layer are (37.2) $\mathrm{m}$ and (4.31) Ohm.m respectively which represent the moderate-hard zone; 
TABLE 3: THE CHEMICAL ANALYSIS OF SOIL INSIDE AREA UNDERSTUDY

\begin{tabular}{|c|c|c|c|c|c|c|c|c|}
\hline BH No. & $\begin{array}{l}\text { Depth } \\
(\mathrm{m})\end{array}$ & $\begin{array}{l}\mathrm{SO}^{-3} \\
(\%)\end{array}$ & Gyp. (\%) & TSS (\%) & $\begin{array}{l}\text { ORG } \\
(\%) \\
\end{array}$ & $\begin{array}{l}\mathrm{CaCO}_{3} \\
(\%)\end{array}$ & PH & $\begin{array}{l}\mathrm{Cl}^{-} \\
(\%)\end{array}$ \\
\hline \multirow{7}{*}{ BH.1 } & $1-1.5$ & 0.37 & 8.26 & 10.71 & 0.029 & 10.0 & 8.1 & 0.063 \\
\hline & $2-2.5$ & 0.57 & 8.40 & 10.97 & - & 11.0 & 8.0 & 0.058 \\
\hline & $3.5-4$ & 0.64 & 11.59 & 13.14 & - & 13.0 & 8.0 & 0.050 \\
\hline & $5.5-6$ & 0.78 & 11.63 & 13.40 & - & 14.0 & 8.1 & 0.044 \\
\hline & $7.5-8$ & 0.89 & 10.72 & 13.61 & - & 16.0 & 7.9 & 0.031 \\
\hline & $8.5-9$ & 0.96 & 13.31 & 15.27 & - & 17.0 & 8.1 & 0.026 \\
\hline & $9.5-10$ & 1.17 & 13.28 & 16.45 & - & 19.0 & 8.0 & - \\
\hline \multirow{3}{*}{ BH.2 } & $12-12.5$ & 1.25 & 12.35 & 15.60 & - & 22.0 & - & - \\
\hline & $14-14.5$ & 1.38 & 14.44 & 17.82 & - & 24.0 & - & - \\
\hline & $16.5-17$ & 1.43 & 12.92 & 15.35 & - & 28.0 & - & - \\
\hline \multirow{3}{*}{ BH.3 } & $18-18.5$ & 1.51 & 14.24 & 17.76 & - & 31.0 & - & - \\
\hline & $19-19.5$ & 1.70 & 13.41 & 16.11 & - & 32.0 & - & - \\
\hline & $20-20.5$ & 1.82 & 15.53 & 18.35 & - & 35.0 & - & - \\
\hline \multirow{10}{*}{ BH.4 } & $1-1.5$ & 0.34 & 7.31 & 9.65 & - & 12.0 & 8.0 & 0.062 \\
\hline & $2-2.5$ & 0.55 & 8.42 & 10.97 & - & 14.0 & 8.1 & 0.053 \\
\hline & $3.5-4$ & 0.67 & 10.53 & 12.20 & - & 17.0 & 8.0 & 0.044 \\
\hline & $6.5-7$ & 0.73 & 11.75 & 14.48 & - & 18.0 & 8.0 & 0.031 \\
\hline & $8.5-9$ & 0.87 & 11.81 & 14.68 & - & 20.0 & 7.9 & - \\
\hline & $10.5-11$ & 0.92 & 12.32 & 15.24 & - & 23.0 & 8.1 & - \\
\hline & $12.5-13$ & 1.11 & 13.26 & 16.37 & - & 25.0 & - & - \\
\hline & $14.5-15$ & 1.24 & 11.80 & 15.06 & - & 28.0 & - & - \\
\hline & $16.5-17$ & 1.40 & 14.31 & 17.62 & - & 32.0 & - & - \\
\hline & $18.5-19$ & 1.67 & 15.18 & 18.23 & - & 33.0 & - & - \\
\hline
\end{tabular}

TABLE 4: BEARING CAPACITIES FOR SOILS IN ALL DRILLED BOREHOLES

\begin{tabular}{|c|c|c|c|c|c|c|c|}
\hline \multirow{4}{*}{ 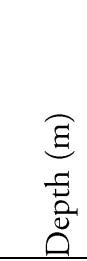 } & \multicolumn{5}{|l|}{ Site-1 } & \multirow{2}{*}{\multicolumn{2}{|c|}{$\begin{array}{l}\text { Site-2 } \\
\text { BH.4 }\end{array}$}} \\
\hline & \multirow{2}{*}{\multicolumn{3}{|c|}{$\mathrm{SPT}(\mathrm{N})$ total for $300 \mathrm{~mm}$}} & \multirow{3}{*}{$\begin{array}{l}\text { Average } \\
\text { SPT(N) Total } \\
\text { for } 300 \mathrm{~mm}\end{array}$} & \multirow{3}{*}{$\begin{array}{l}\text { Ave. B.C } \\
T / \mathrm{m}^{2}\end{array}$} & & \\
\hline & & & & & & \multirow{2}{*}{$\begin{array}{l}\text { SPT(N) total } \\
\text { for } 300 \mathrm{~mm}\end{array}$} & \multirow{2}{*}{$\begin{array}{l}\text { Ave. B.C } \\
T / \mathrm{m}^{2}\end{array}$} \\
\hline & BH.1 & BH.2 & BH.3 & & & & \\
\hline 1.0 & - & - & - & - & 9.5 & - & 8.5 \\
\hline 2.0 & - & - & - & - & 13 & - & 11.0 \\
\hline 3.0 & 28 & 48 & 47 & 41 & 14.5 & 26 & 10.6 \\
\hline 6.0 & $50 / 6^{\prime \prime}$ & 45 & 41 & 45 & 15.6 & 61 & 19.7 \\
\hline 9.0 & 50/4" & $50 / 4 "$ & $50 / 5^{\prime \prime}$ & $50 / 4 "$ & 17.0 & 25 & 10.4 \\
\hline 12.0 & $50 / 4 "$ & $50 / 4 "$ & $50 / 6^{\prime \prime}$ & $50 / 5^{\prime \prime}$ & 17.0 & $50 / 6^{\prime \prime}$ & 17.0 \\
\hline 14.0 & - & $50 / 4 "$ & $50 / 4 "$ & $50 / 4 "$ & 17.0 & $50 / 3^{\prime \prime}$ & 17.0 \\
\hline 15.5 & - & $50 / 4 "$ & $50 / 4 "$ & $50 / 4 "$ & 17.0 & - & - \\
\hline 16 & $50 / 4 "$ & - & - & $50 / 4 "$ & 17.0 & - & - \\
\hline 17.0 & 50/4" & - & - & $50 / 4 "$ & 17.0 & $50 / 4^{\prime \prime}$ & 17.0 \\
\hline 20.0 & $50 / 4 "$ & 51 & $50 / 4^{\prime \prime}$ & 50/4" & 17.0 & $50 / 4 "$ & 17.0 \\
\hline
\end{tabular}



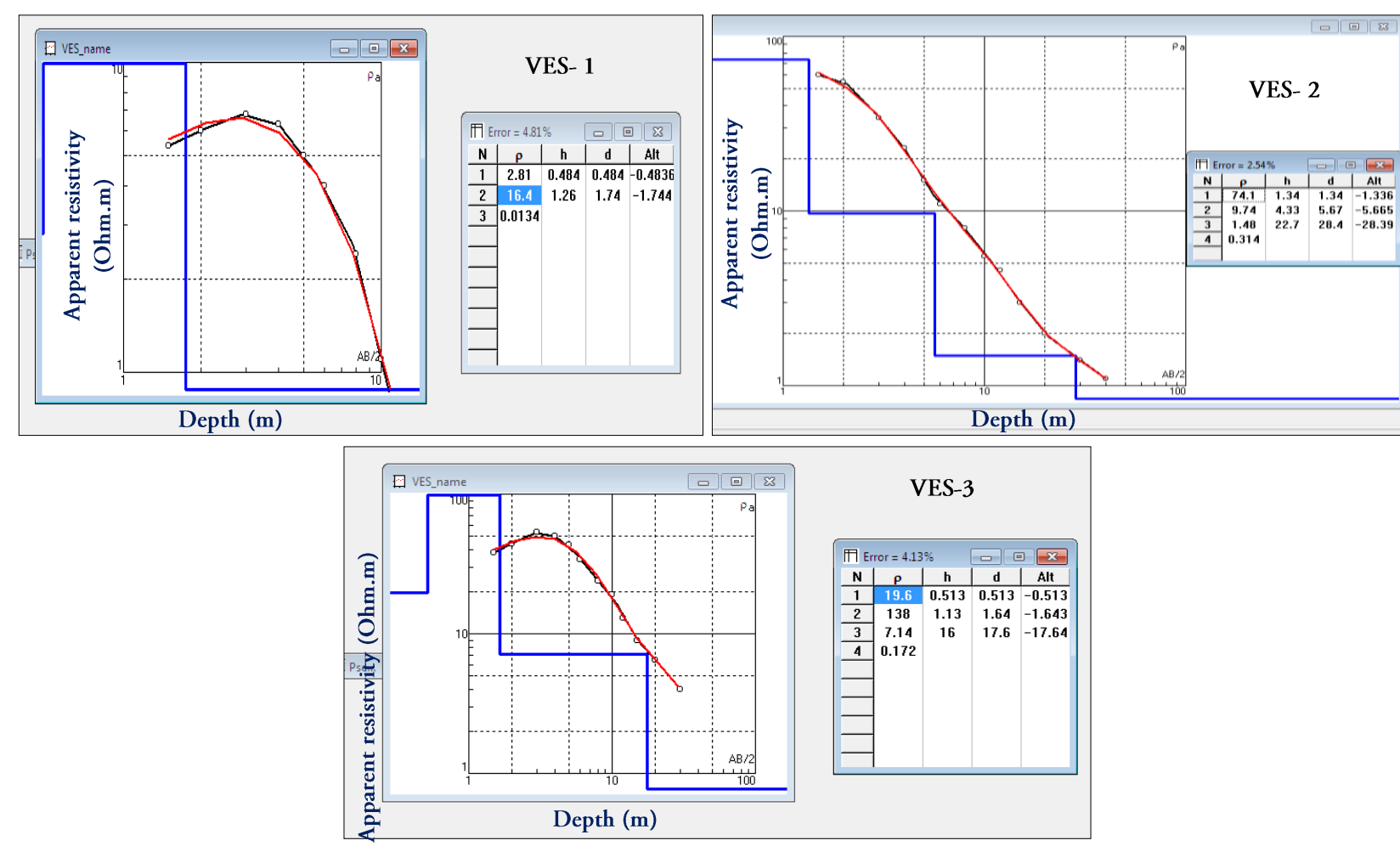

Fig.8. Shows the VES field curves of Site1
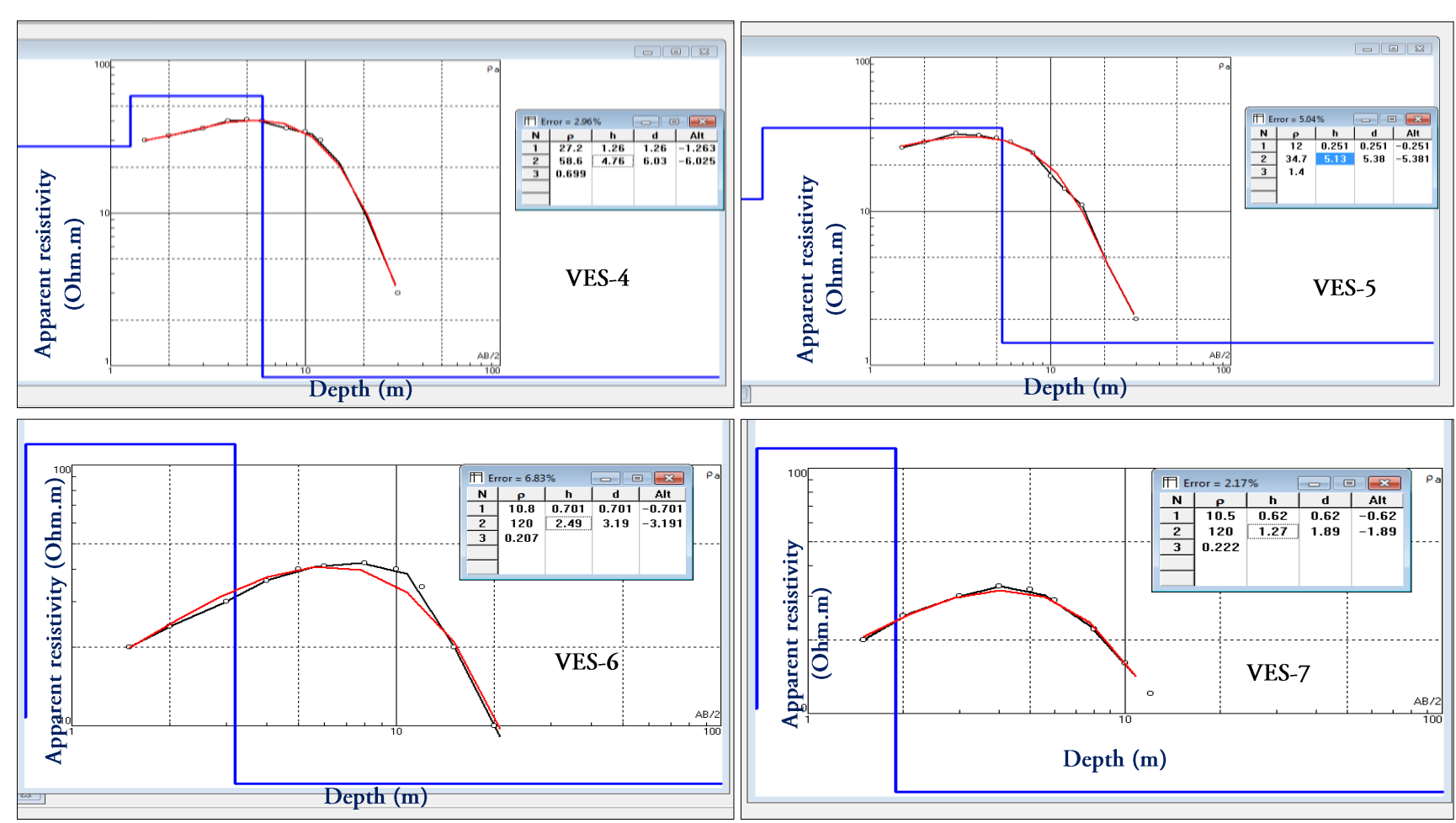

Fig.9. Shows the VES field curves of Sites 2 
while the last layer has the lowest resistivity values $(0.243)$ Ohm.m that referred to the consolidation process of this layer (Table-5).

TABLE 5: RESISTIVITY VALUES (OHM.M) AND THICKNESSES (M) OF THE UNDERLYING LAYERS OF THE STUDIED AREA

\begin{tabular}{|l|c|c|c|c|c|c|c|c|}
\hline \multirow{2}{*}{ VES No. } & \multicolumn{2}{|l|}{ Layer-1 } & \multicolumn{2}{|l|}{ Layer-2 } & \multicolumn{2}{l|}{ Layer-3 } & \multicolumn{2}{l|}{ Layer-4 } \\
\cline { 2 - 9 } & $\rho 1$ & h1 & $\rho 2$ & h2 & $\rho 3$ & h3 & $\rho 4$ & h4 \\
\hline 1 & 2.81 & 0.4 & 16.4 & 1.28 & 0.013 & - & - & - \\
\hline 2 & 74.1 & 1.3 & 9.74 & 4.33 & 1.48 & 22.7 & 0.31 & - \\
\hline 3 & 19.6 & 0.5 & 138 & 1.13 & 7.14 & 16 & 0.17 & - \\
\hline 4 & 27.2 & 1.2 & 58.6 & 4.76 & 0.699 & - & - & - \\
\hline 5 & 12 & 0.2 & 34.7 & 5.13 & 1.4 & - & - & - \\
\hline 6 & 10.8 & 0.7 & 120 & 3.19 & 0.207 & - & - & - \\
\hline 7 & 10.5 & 0.6 & 120 & 1.27 & 0.222 & - & - & - \\
\hline
\end{tabular}

By the comparison between the VES curves in both Site-1 and 2, it appears that the second layer has the highest resistivity values between (120-138) Ohm.m in the area which is restricted between (0.987-7.56) meters as average depth. It probably represents the existence of cavities and weak zones within these shallower depths (SPT ranged from 26 to 50$)$.

\section{b. Radar sections}

The GPR anomalies can be identified in some situations even in the field; however, it is often essential to process the data before further interpretation. During processing, it is possible to improve the quality of the images derived from subsurface features. This step is performed in order to view and check the quality of the collected profiles (raw data) in the field, and therefore, to observe if these profiles are effective, and contain potential target anomalies or not. This procedure makes the GPR in many cases of investigations more effective, Telford et al., [17]. The profiles were imported into Rad Explorer Version 1.4 software, in order to show the quality of these profiles which come directly from the field without any type of processing. However, raw data processing such as DC-removal, timezero adjustment, trace edit, background removal and band pass filters were done for all radar sections.
Two GPR radargrams over main hole and cables were conducted as real examples locates at the western parts of Site-1, and processed using predictive deconvolution filter in addition to the common filters. This type of filter was used for the first time and it enhances the signals resolution. As a result, deconvolution can be both difficult to apply systematically and exhibit little enhancement in resolution. Instances where deconvolution has proven beneficial occurred when extraneous reverberation or possibly system reverberation have been involved. Deconvolution can then provide substantial pulse compression benefits, Annan [18].

The bottom of the main hole extension was predicted and the total depth of it matches the real depth $(2 \mathrm{~m})$, however the water table inside hole is seen at $1.4 \mathrm{~m}$. It is worthwhile to mention here that the GPR profile was on concrete passage way, i. e., not along low a resistive top layer which causes high attenuation for the radar signal and consequently its penetrating depth (Fig.11).

The depth of the electrical cables was not known in the study area. The resulted radargram have indicated that, for an example, cables buried at the western parts of Site-1, shows clear signal responses and cables were recognized at (1.36) $\mathrm{m}$ (Fig.12).

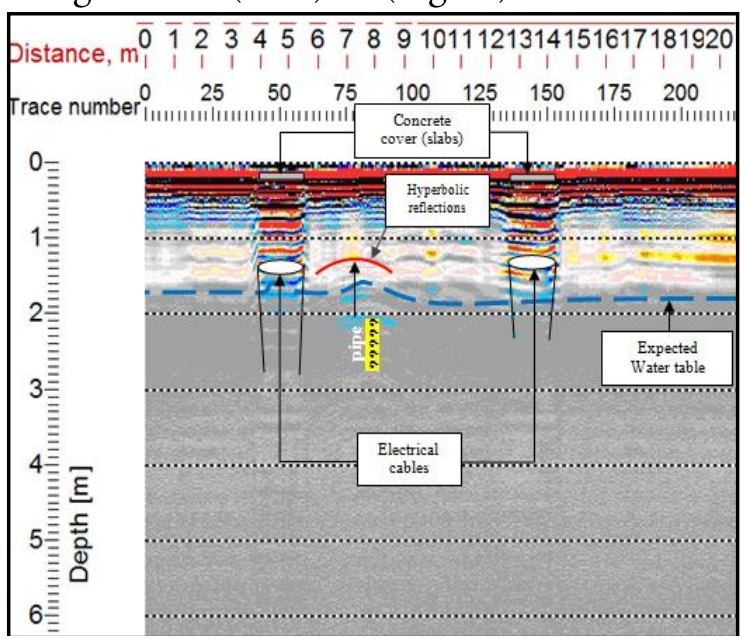

Fig.11> Shows the interpreted radargram for the Main hole 


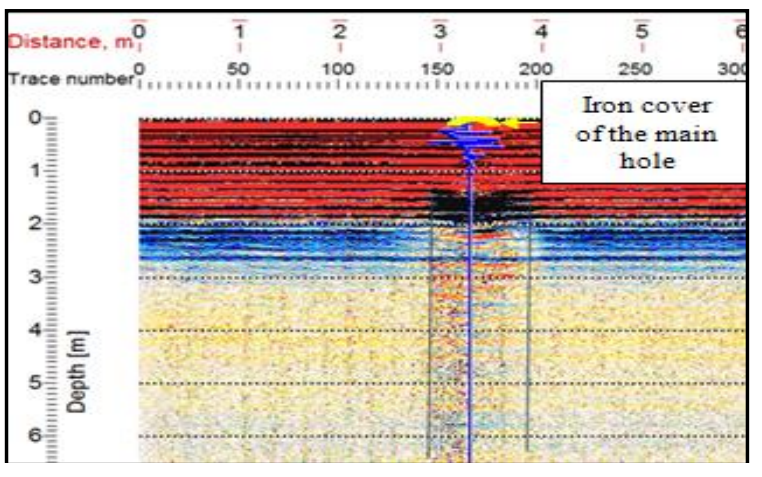

Fig.12. Shows the interpreted radargram for the electrical cables

We also noticed that the detection of these cables is much easier from the GPR profiles run for buried objects. At the same location of the discovered cables, a possible pipe might exist in between at similar depth $(1.36 \mathrm{~m})$; however it gives clear hyperbolic reflections. Because the radar waves were disappeared via depth at $1.6 \mathrm{~m}$ due to signals attenuation, so it should be pointed out through this fact that the water table is found near this depth. GPR radargrams had been conducted in May, 2012 using $250 \mathrm{MHz}$ antenna and setting $190 \mathrm{~ns}$ time windows, medium maximum time window, autostack including different trace intervals along all profiles, in order to detect different unknown buried bodies inside the studied sites. From the images of our work, it is hard to recognize the shape of the objects. Image of an object generated by GPR is not corresponding to its real geometrical representation. In interpreting the radar data, one usually searches for anomalies such as hyperbolic reflections, irregularities in largely uniform reflection patterns, and changes in the frequency of the signals. Hyperbolic reflections are caused by point reflectors in the ground such as pipes, rocks, voids etc. Irregularities are usually caused by disturbances to the natural sedimentation of soil as a result of construction activities. Changes in frequency of radar signals are caused by changes in the dielectric properties of the transmitting medium, e.g., due to saturation by water which lowers the width of radar signal, Hunaidi and Giamou [19]. According to the high quality referred to GPR radargram of $5 \mathrm{~cm}$ trace interval, the point reflectors and irregularities in reflection patterns correspond to filled old iron pipes (have moderate to low electrical conductivities) is believed to be the water pipe. Since this pipe is so difficult to detect due to the partly absence of hyperbolic reflections. Because of the variety sizes of the buried pipes, top of some of them had been hardly picked at a depth of about 1 meter rather than the pipe's actual $1.3 \mathrm{~m}$ depth (perhaps due to an inaccuracy of the measured radar velocity and soil characterization). This might be taken as an indication of a slow-down in the radar waves due to the natural saturation of the soil. It is hard to tell if these signs are related to that body if we do not know previously the body location. The top soil at this time of the year is semi conductive and it should be pointed out that the soft silty and clayey sand soils in the area under_study were strongly affect negatively towards the GPR response, therefore most of the buried bodies are difficult to recognize in spite of their own sizes and resistivities. Water has a high dielectric constant, so that radar waves travel more slowly in water saturated ground. Here, the saturation condition might altered inside the sites owed to the continuous waste (water and pollutes) infiltration from surface into the ground and groundwater discharging influence, therefore soil in situ may wash out. It is believed that water has its positive action upon the media and reduces wave attenuation at shallower depths. In fact, the soil of the investigated area being more saturated with fresh-brackish water, the matter which lowers the electrical conductivity of the surroundings around buried objects and the hyperbolic reflections were partly appeared. For the 
conducted profiles, there are faint signals that could reflect the buried bodies. However, these signals are not showing clear parabola, which should come out of the normal radar wave reflections. Yet, we can say that the 250 $\mathrm{MHz}$ antenna frequency has showed more than 2.5 meter penetrating depth for the study soil. It gives satisfied radar sections and the hyperbolic reflections related to the buried bodies are being clear.

Pipes filled with water, cables and weak zones or even cavities were easily extracted from radar sections during the above surveys. We can differentiate between pipes and caves from almost their reflectivity and response spreading seen in radargrams. Moreover, the exact locations of these bodies were checked by the direct surface observations, available maps or even drilling. These encourage results perhaps due to the enhancing happened due to the signal penetrating (less radar attenuation). Figures 13, 14 and 15 show the interpreted GPR sections for such profiles. As a result, it is concluded that the area under_study was subjected to continuous alternative conditions during arid and humid seasons. This make water table always has different level within the soil and therefore different water content which hardly affect the resistivity values. So, GPR might work here or not depending on the climate condition. Also, from the engineering soil investigations, the main problem that could be encountered during the life of the establishment is the presence of soluble salts in the most underlying layers; this can be explained as the effect of soil engineering properties variations, due to presence of high gypsum, total soluble salts contents and the fluctuation of water table. Fluctuation of water table could make a leaching process to the subsurface materials underneath the foundation. The leaching process can be defined as the removal of soluble matters and dissolution of the cementing agents from soil either by water table fluctuation or by percolation of water into soil. The action of leaching may change the engineering properties of soils, especially compressibility, shear strength, collapsibility and permeability. In turn, it affects the performance of the structures established within such soils.

\section{CONCLUSION}

1.Continuous leakage of the industrial effluent water from the processing units of Site-2 leads to dissolution of the soil cementing media and hence forming caves and channels through the soil.

2. Washing out of fine clay grains from the soil structure leads to degrading of soil characteristics, especially it's bearing capacity.

3.Depending upon the results of the GPR survey, caves and weak zones were detected at all parts of the studied sites. These zones are randomly present and distributed according to the distance away from the leaking areas.

4.From both engineering and geophysical interpretations, it seems that Site-2 is less subjected to soil settlement problem rather than Site-1.

As general, to avoid problems of foundation on such soil, two kinds of provisions are usually considered; first, making the structure more resistant to damage from soil movement, and this can be done by strengthening the structure to withstand movement; and second by replacing the top soil layer and / or the zone beneath the base footing. According to soil characteristics and caving volumes, cement grouting can be used to treat the caves and weak zones in order to cease the settlement problem in its present situation. 

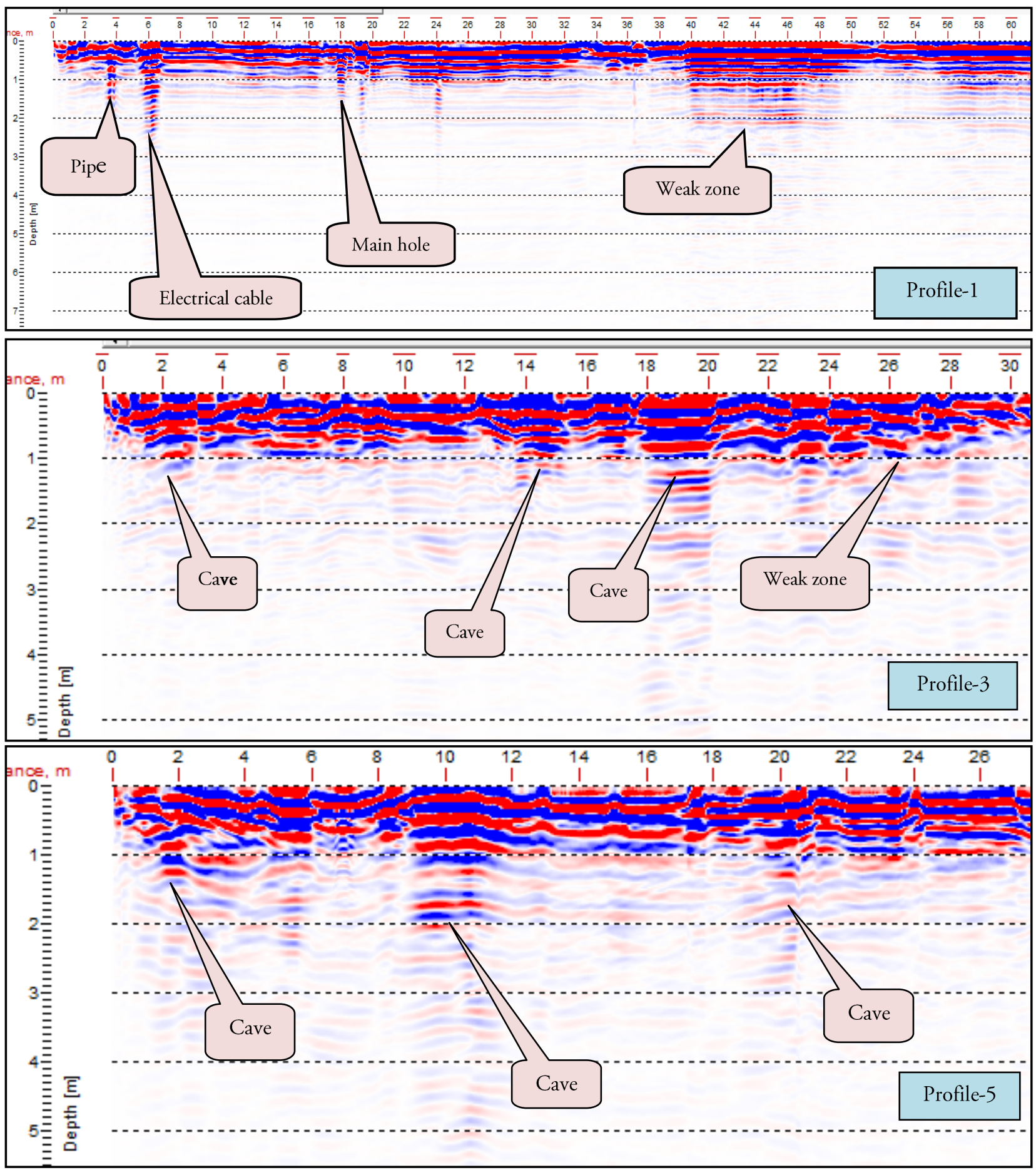

Fig.13 Interpreted radargrams along profiles 1, 3 and 5 (Site-1) 

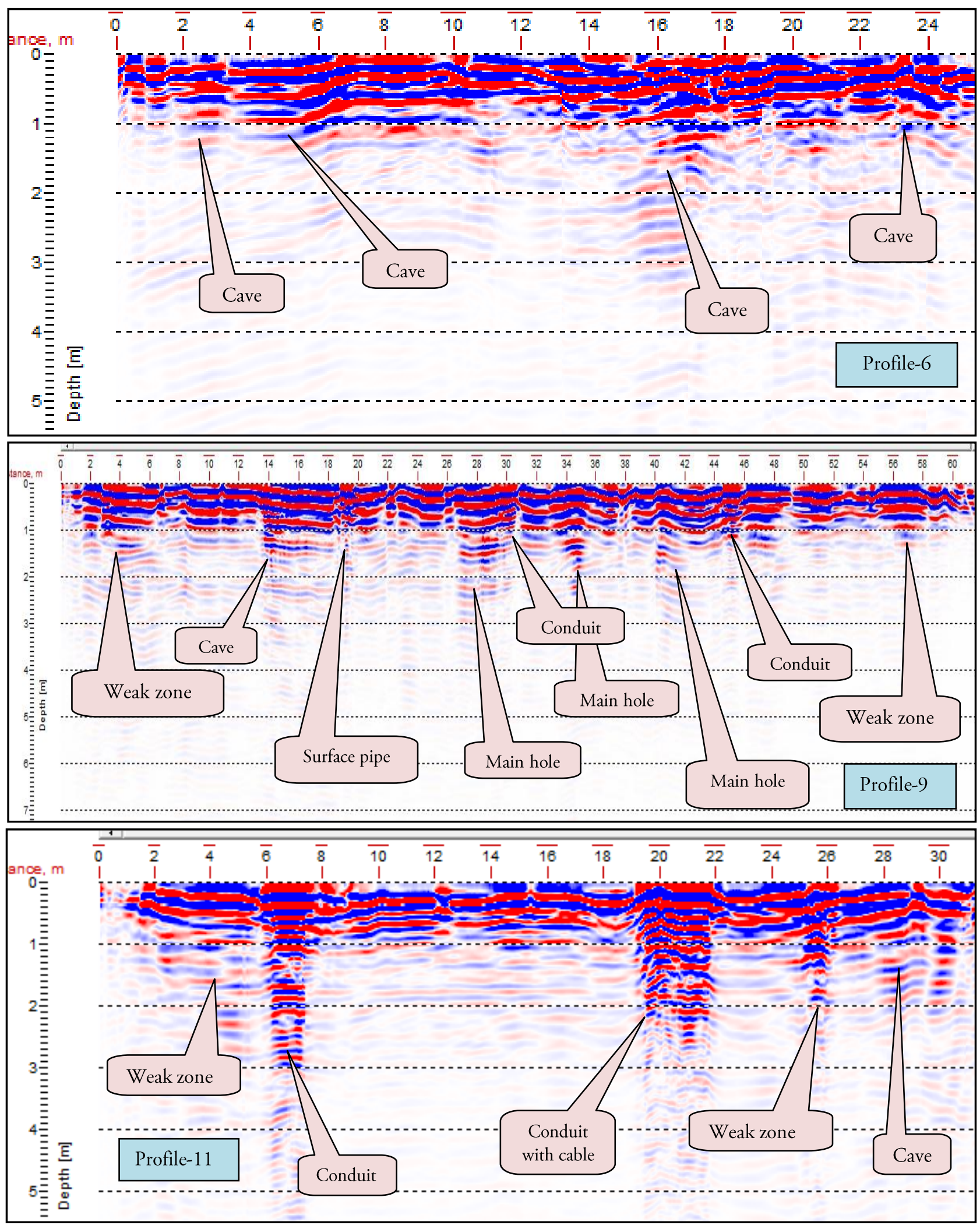

Fig.14 Interpreted radargrams along profiles 6, 9 and 11(Site-1) 


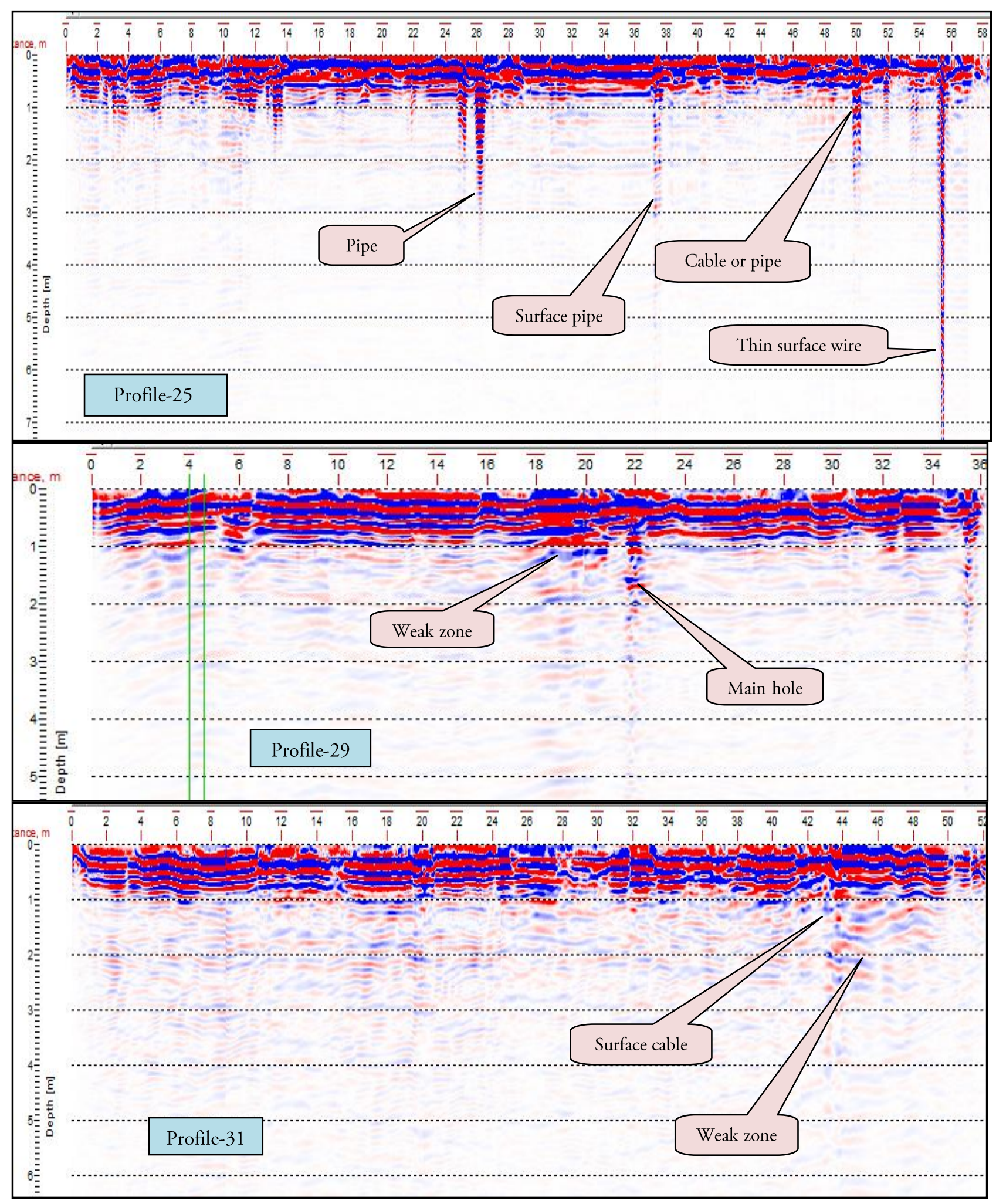

Fig.15 Interpreted radargrams along profiles 25, 29 and 31 (Site-2) 


\section{ACKNOWLEDGMENT}

The author is highly grateful to Dr. Mowafaq F. Al-Shahwan for his great assistance in the field works.

\section{REFRENCES}

[1] Buday, T.; The Regional Geology of Iraq; Stratigraphy and Paleogeography, Dar Al- Kutub Publ. House, Mosul, Iraq, 445 P, 1980.

[2] Griffin, R. H.; Geophysical exploration for engineering and environmental investigations, US Army corps of engineers, Washington, 204P. , 1995

[3] Al-Ani, J. M. T.; Investigation of subsurface cavities using electrical resistivity method in Hammam Al-Aleel area, Iraqi J. of geological society, Vol.26, No.1, PP. 13-26 (in Arabic), 1993.

[4] Al-Jiboury, A. A.; Application of electrical resistivity method in an hydroelectrical power site, Unpublished, Msc. Thesis, University of Baghdad, 98 P, (in Arabic) , 1994.

[5] Al-Khersan, E.H.. Detection of cavities and soil settlements in an industrial site using electrical resistivity method, southern Iraq, J. Basrah Researches, Vol.29, Part2, PP 1-17, 2004.

[6] Saeed, H., GPR Method and its Engineering Applications in Baghdad University Site, M.Sc Thesis, College of Science, University of Baghdad, (Unpublished), 2010.

[7] Al-Khafaji, A. J. M., Geophysical and Geotechnical Investigations of Soil Underneath the Foundation of Al-Abbas Holy Shrine Site in Kerbala`a Governorate, Ph.D Thesis, College of Science, University of Baghdad, (Unpublished), 2010.

[8] Al-Khazali, I. A., Application of Ground Penetration Radar technique to explore such Basrah low resistivity soils,, southern Iraq, M.Sc Thesis, College of Science, University of Basrah, (Unpublished) , 2012.

[9] Sharma, P.V., Geophysical Methods in Geology, $2^{\text {nd }}$ Edition, Elsevier Scientific Publishing Company, 442 P, 1986.

[10] Al-Menshed, F. H. K.; Evaluation of resistivity method in delineation groundwater hydrocarbon contamination Southwest of Karbala city, Ph.D
Thesis, College of Science , University of Baghdad, (Unpublished), 2011.

[11] Dobrin, M. B. and Savit, C. H.; Introduction to geophysical prospecting, 4th edition, McGrawHill, New York, 865 P, 1988.

[12] Conyers, L. B., Ground-penetrating radar for landscape archaeology: Method and applications, Department of Anthropology, University of Denver, Colorado, USA, 2009.

[13] Stolarczyk, L. G., Peng, S. S., Advanced Electromagnetic Wave Technologies for the Detection of Abandoned Mine Entries and Delineation of Barrier Pillars, a Research Presented to Mine Safety and Health Administration (MSHA) and Office of Surface Mining Reclamation and Enforcement (OSMRE), Published in Internet, 65 P, 2003.

[14] Flohrer, C., and Popel, M., "Combination of a covermeter with a GPR-system: A tool for detecting pre-stressed bars in concrete structures."Proc. 6th Int. Conf. on Ground Penetrating Radar, Dept. of Geoscience and Technology, Tohoku Univ., Sendai, Japan, PP: 273-277, 1996.

[15] Martinz, A. and Byrnes, A. P., Modeling dielectric constant values of geologic materials: An aid to ground penetrating radar data collection and interpretation, Earth Sciences, Bulletin 247, part-1, 2001.

[16] Zohdy, A.A.R.; The auxiliary point method of sounding interpretation and its relationship to Dar Zarrouk parameters, Geophysics, Vol.30, PP. 644-660, 1965.

[17] Telford, W.M., Geldart, L.P., Sheriff, R.E.. Applied Geophysics. Cambridge Univ. Press, England, 1990.

[18] Annan A. P., Practical Processing of GPR Data, Sensors and Software Inc. 16 P. , 1999.

[19] Hunaidi, O., Giamou, P., Ground-penetrating radar for detection of leaks in buried plastic water distribution pipes, 7th International Conference on Ground Penetrating Radar, Lawrence, Kansas, 27-28, PP: 783-786 http://irc.nrc-cnrc.gc.ca, 1998. 


\title{
إستخدام إختراق الأرض بالر ادار لإستكثاف الأمور المدفونة والفجوات والمناطق الضعيفة بداخل حقل نفطي بجنوب
}

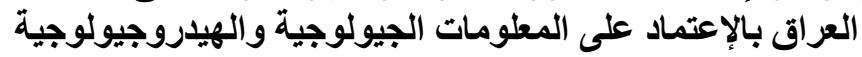

\author{
عماد الخرسان \\ كلية العلوم ، جامعة البصرة، العراق
}

الملخص:

تم أختيار سبعة نقاط جس كهربائي عمودي بترثيب شلمبرجر و أثنان وثلاثون مسار جيور اداري على أساس مبدأ التغطية المتكاملة لمنطقة الدر اسة التي تمثل موقعا صناعيا يقع جنوب العر اق / محافظة البصرة . كما تم أنجاز تحريات جيوتقنية و هيدروجيولوجية أستخدت كأدوات مساعدة للكثف عن منسوب المياه الجوفية ، فضلا عن تو اجد الأجسام المدفونة و التكهفات وأنطقة الضعف الحاصلة في تربة الموقع قيد الدراسة ـ تم ملاحظة العديد من الثو اذ في قيم المقاومة النوعية و المقاطع الجيور ادارية التي فسرت بعد ذلك لتدل على تو اجد التكهفات وأمتدادتها 